\title{
ЗИГМУНД ФРЕЙД МІЖ НАТУРАЛІЗМОМ ТА ТРАНСЦЕНДЕНТАЛІЗМОМ: ВАРІАЦІЇ НА ТЕМУ БЛЮМЕНБЕРГА
}

\author{
В.І. Менжулін
}

150-й річниці від дня народження Зигмунда Фрейда присвячуетъся

Дана стаття базується на матеріалах доповіді, підготовленої для виступу перед студентами-психологами Національного університету ім. Т.Шевченка 22 грудня 2005 р. в рамках курсу «Філософія психології», що читається викладачем кафедри філософії філософського факультету к.ф.н. В.І. Кебуладзе. Автор цих рядків був запрошений вельмишановним колегою ${ }^{1}$ п проханням прокоментувати одну принципову тезу, що була висловлена ним студентам раніше та викликала досить сильну дискусію. Коротко ця теза звучить так:

Уникнути вад натуралізму вдається тільки феноменологічній моделі психологічного, в той час як психоаналіз, хоча він i виглядає менш натуралістичним, ніж інші відомі психологічні системи (наприклад, біхевіоризм, функціоналізм, радянська матеріалістична психологія та ін.), тим не менш несе на собі родимі плями психологічного натуралізму і претендувати на статус посправжньому трансценденталістської програми не може.

\footnotetext{
${ }^{1}$ Автор глибоко вдячний панові Кебуладзе не тільки за запрошення виступити, але й за те, що вже після того, як доповідь набула вигляду статті, він переглянув iї текст та запропоновував цілу низку надзвичайно важливих уточнень та виправлень.
}

Актуальні проблеми духовності

(Відп. ред.: Я.В. Шрамко)

Кривий Ріг (2006), 67-86 
На нашу думку, це надзвичайно актуальна, принаймні для вітчизняного інтелектуального простору, постановка питання. У 2005-му році в українського читача, що цікавиться ідейною спадщиною Фрейда, з'явилася можливість познайомитися з одним дуже важливим текстом, в якому проблема натуралізму в психоаналізі відіграє значну роль. Цим текстом є глава «Розшифрування сновидінь» у книзі видатного німецького філософа та історика ідей Ганса Блюменберга «Світ як книга» [1].

Присвячена Фрейду глава з книги Блюменберга, на нашу думку, цікава, серед іншого, тим, що її автор вдало реалізує переваги позиції «незаангажованого спостерігача» ${ }^{2}$ та привертає увагу до тих пунктів, про які прихильники психоаналітичного руху (великою мірою-з подачі його фундатора) або говорять неохоче, або говорити відмовляються, або навіть не здогадуються.

Блюменберг, наприклад, стверджує, що, вивчаючи тексти Фрейда, він натрапив на одну висловлену «побіжно, але доволі зрозуміло» [1, c. 451] ідею. На нашу думку, варта уваги вже сама фразеологія, обрана Блюменбергом. Висловом «побіжно, але доволі зрозуміло» він надзвичайно тонко передає амбівалентне ставлення автора цієї ідеї до розкриття її змісту: Фрейд її розкриває («доволі зрозуміло»), але робить так, що винайти інформацію про це розкриття стає досить складно (надає їі лише «побіжно»). Фактично, у даному випадку Фрейд діє як сновидіння за його власною теорією - повідомляє (розкриває), але одночасно й втаємничує (маскує). Доки залишимо відкритим питання про те, яка інстанція виступила у даному випадку в ролі «цензурної» і змусила засновника психоаналізу висловлювати цю ідею саме таким амбівалентним чином, а зараз власно про їі зміст. Блюменберг вичитав у Фрейда ось що:

Ідеал психоаналізу полягає у зведенні всіх психічних процесів до хімічних реакцій. $\langle\ldots\rangle$ «Душа» $є$ тільки попереднім поняттям на позначення того, що, як хімічний комплекс, надто далеко, можливо навіть безнадійно, ухиляється від нашого реального аналізу. $\langle\ldots\rangle$ Наукова система психоаналізу, яку ми створили, е насправді надбудовою, яку колисъ треба сперти на

\footnotetext{
${ }^{2}$ Коло інтелектуальних інтересів та уподобань Ганса Блюменберга виходило далеко за межі психоаналізу. Відштовхуючись від феноменології Гусерля, він прийшов до створення власної оригінальної системи філософських поглядів - метафорології. Психоаналіз його цікавив лише як одна із сторінок в «історії ідей, зорієнтованої на дослідження метафоричних джерел і відозмін абстрактних філософських понять» $[1$, с. 11$]$.
} 
органічний фундамент. Однак ивого фундаменту ми ще не зна$\epsilon \mathcal{M} O[1$, c. 451$]$.

В контексті теми даної статті цю знахідку Блюменберга можна кваліфікувати як відкриття у Фрейда досить чітких висловів на користь радикального натуралізму як ідеалу психологічного знання. Наведене зізнання Блюменберг знайшов у лекції, що була прочитана Фрейдом за часів Першої світової війни, тобто тоді, коли йому було близько 60 років і він вже отримав всесвітне визнання як лідер нового наукового напрямку. Однак, за Блюменбергом, переконаність у тому, що останнє слово у вирішенні фундаментальних психологічних питань належить хімії, Фрейд проніс через все життя i, взагалі, як каже Блюменберг, «вперто» зараховував психологію до природничих наук [1, c. 452]. Беззаперечна академічна репутація Блюменберга, а ще більшою мірою зміст наведених ним цитат відповідного гатунку, не дозволяють сумніватися у наявності подібного панхімізму (і відповідно - домінування природної настанови) в підгрунті Фрейдової теорії.

Більш того, якщо взяти до уваги дані з наукової біографії Фрейда, що наводяться у більш спеціалізованих дослідженнях з історії психоаналізу, то можна знайти додаткові підтвердження давнього і глибокого альянсу засновника психоаналізу з натуралістичним підходом. Почати хоча б з того, що за базовою освітою Фрейд був лікарем. Ідентифікація з медичним професійним цехом взагалі майже завжди означає однозначну орієнтацію у бік наукового натуралізму. Епоха, коли цій професії навчався Фрейд (початок останньої чверті XIX ст.), не тільки не була виключенням, а скоріше має бути визнаною періодом майже тотальної домінації цього правила. Про медицину (зокрема психіатрію та неврологію) тих часів мовою феноменології можна сказати, що вона перебувала в абсолютному полоні фактичності, тобто природної настанови з її безумовною вірою в очевидність емпіричних фактів та у пояснювальну силу таких принципів, як фізикалізм, редукціонізм та каузальний детермінізм.

Впродовж років, проведених у Віденському університеті (рік вступу - 1873), Фрейд, хотів він того чи ні, змушений був віддати належне типово медичному культові натуралізму. Наявність в інтелектуальній біографії Фрейда досить тривалого періоду, коли він перебував під впливом домінуючих на той час натуралістичних уявлень стосовно неврології та психіатрії, дозволила класику історії психіатрії Анрі $\Phi$. Еленбергеру $^{3}$ піддати сумніву дуже поширену серед його колег тезу

\footnotetext{
${ }^{3}$ Його праця «Відкриття несвідомого: історія та еволюція динамічної психіатрії»
} 
про те, що в еволюції поглядів Фрейда було лише два періоди: до-психоаналітичний та психоаналітичний. За Еленбергером, всередині «допсихоаналітичного» періоду насправді мали місце дуже суттєві трансформаційні процеси і в ньому самому можна виокремити декілька фаз. Для нашого дослідження дуже важливо, що першу фазу «до-психоаналітичного» періоду Фрейд провів, якщо слідувати логіці викладу Еленбергера, безпосередньо в межах традиції, яка, поза сумнівом, може кваліфікуватися як суто натуралістична. Ця фаза еволюції уявлень Фрейда описується Еленбергером у підрозділі, натуралістичний зміст якого відчутний навіть у назві - «Від мікроскопічної анатомії до теоретичної неврології» [7, с. 474-477].

3 цього джерела можна дізнатися про те, що будучи ще зовсім юним (19 років) студентом, Фрейд присвятив багато часу та сил дослідницькій роботі в Інституті порівняльної анатомї під керівництвом проф. Карла Клауса. Результати мікроскопічного дослідження, проведеного юним Фрейдом з метою встановлення гонадної структури вугра, справили на керівника не аби яке враження і він навіть представив підсумковий звіт свого підопічного на розгляд у Віденську Академію наук. Після цього Фрейд протягом шести років не менш успішно займався анатомічними студіями під керівництвом проф. Ернста Брюке. За цим вченим закріпилася слава ярого супротивника будь-яких проявів віталізму та фіналізму у медицині та, відповідно, статус затятого прихильника зведення всіх психічних процесів до фізіологічних, а фізіологічних - до фізичних та хімічних ${ }^{4}$.

Після закінчення університету (1883) Фрейд влаштувався на роботу до психіатричного відділення Віденського госпіталю, але це в жодному разі не означало завершення періоду перебування у науково-позитивістському «полоні фактичності». Тут його керівником став відомий анатом Теодор Мейнерт, погляди якого згодом отримали назву «міфологія мозку» - внаслідок надмірної схильності цього вченого описувати всі психологічні та патопсихологічні феномени виключно в термінах структур мозку, причому не тільки таких, що реально існують, але й гіпотетичних (найчастіше - зовсім фантастичних). Залишивши Віденський госпіталь і звільнившись від опіки Мейнерта, Фрейд, утім не поспішив до лав антинатуралістів, а замість цього

[7] є одним з найбільш фундаментальних та широко визнаних досліджень з історії психоаналізу.

${ }^{4}$ Результати дослідження з анатомії мозку, проведеного Фрейдом під керівництвом цього апологета натуралізму, були опубліковані у вигляді окремої статті: «Про структуру елементів нервової системи» [8]. 
зайнявся дослідженням церебрального паралічу. Навіть ще пізніше (у 1895 р., тобто через 22 роки після початку академічної кар'єри), працюючи над «Проектом наукової психології», Зигмунд Фрейд, замість того, щоб відмовитися від традиції своїх наставників, здійснив досить масштабну спробу проінтерпретувати психічні феномени у термінах анатомії мозку й нервової енергії. У цій праці він у найкращих традиціях «міфології мозку» пояснював психологічні феномени в термінах розподілу і циркуляції енергії, що буцімто відбуваються за допомогою гіпотетичних матеріальних структур мозку (нейронів).

Якщо взяти до уваги наведені факти щільної та тривалої аффіліації молодого Фрейда із могутнім натуралістичним рухом (європейською медициною кінця XIX ст.) та додати до цього інформацію Блюменберга про те, що і в більш пізні роки (вже після створення власної психологічної школи) засновник психоаналізу зберіг переконаність у фундаментальній істинності природної настанови, то його засадничий натуралізм може здатися остаточно встановленим. Однак, не все так просто.

Справа у тім, що майже з самого початку в аффіліації Фрейда 3 натуралізмом, незважаючи на її щільність, проявилися певні утруднення. Наприклад, у Еленбергера можна знайти вислови про те, що Фрейд, незважаючи на схвальні відгуки про його роботу в анатомічних лабораторіях з боку обох керівників, в різних ситуаціях та джерелах оцінював свій лабораторний досвід по-різному: іноді як позитивний, а іноді-із скепсисом. У Еленбергера також знаходимо інформацію про те, скажімо, що вже навіть в ранніх - суто натуралістичних за своїм предметом - дослідженнях у Фрейда проявилася схильність до надмірних узагальнень умоглядного гатунку. Наприклад, бельгійський фахівець із церебрального паралічу Van Gehuchten ще 1897 р., одразу після публікації результатів фрейдівського дослідження з цього захворювання, знайшов модель, запропоновану молодим колегою із Відня, штучною та позбавленою анатомо-фізіологічного базису ${ }^{5}$.

Одну з версій цієї проблемності у стосунках з натуралізмом можна знайти у нещодавно виданій російською мовою біографії Фрейда, написаній його особистим лікарем Максом Шуром [5]. Аналізуючи листування Фрейда з його близьким приятелем, отоларингологом з Берліну Вільгельмом Флісом, Шур натрапив на цікаве зізнання. 1 січня 1896 р., тобто першого дня того самого року, з яким зазвичай пов'я-

${ }^{5}$ Докладніше про це: [7, с. 477]. 
зують початок розбудови психоаналітичної доктрини ${ }^{6}$, Фрейд написав Флісу:

Я бачу, що, ставши лікарем, ти прагнеш до свого ідеалу зрозуміти людину за допомогою фізіології; я же потай сподіваюся тим самим шляхом досягнути своєї споконвічної метифiлософiї (курсив мій. - B.M.). Я прагнув до цього з самого початку, навіть коли ще не розумів свого місця у цьому світі $[5$, c. 98].

Трьома місяцями пізніше (2 липня 1896 р.) Фрейд повернувся до цієї теми і додав:

Коли я був молодий, для мене не було нічого бажаніше за білософсъке осляння (курсив мій. - В.M.). Зараз я перебуваю на шляху до нього, повернувши від медицини до психології [5, c. 101].

Отже, як з'ясовується, своє перебування у таборі медиків-натуралістів Фрейд від самого початку сприймав лише як очікування вдалого моменту його залишити. Насправді, принаймні за наведеними висловами, він мріяв про психологію, причому таку, яка базується зовсім не на емпіричних спостереженнях, а на філософському осяянні. Тобто тепер вже антинатуралізм Фрейда починає виглядати як встановлений факт. Однак і тут однозначність буде поспішною.

Насправді, ми маємо численні докази принципової нечіткості Фрейда стосовно питання «натуралізм або антинатуралізм», фундаментальної невизначеності, що і знайшла прояв, як у зазначених, так і у багатьох інших ${ }^{7}$ фактах коливання (або точніше - маневрування) між двома конкуруючими інтелектуальними таборами. 3 одного боку це був табір медиків, хіміків, тобто емпіриків та натуралістів, а з іншого - табір прихильників умоглядного філософування, тобто якщо не чистих трансценденталістів або радикальних антинатуралістів, то принаймні не натуралістів.

Що було причиною цієї невизначеності? Що змусило Фрейда стільки часу приховувати свою прихильність до філософії під маскою професійного клініциста? Чому він, будучи закоханим у філософію, вступив до медичного факультету та протягом 20 років старанно робив

\footnotetext{
${ }^{6} 1896$ р. Фрейд приступив до унікального психологічного експерименту - самоаналізу, результатом якого явилося народження психоаналітичної концепції та публікація її засадничого (парадигмального) тексту — «Тлумачення сновидінь» (1900 p.)

7Збільшувати кількість прикладів не дозволяє формат цієї публікації.
} 
медичну кар'єру, а потім ще й говорив, що справжнім фундаментом психології є зовсім не його улюблена філософія, а хімія?

3 тим фактом, що у власній автобіографії Фрейд, говорячи про свої до-університетські зацікавлення, згадує зовсім не філософію, а юриспруденцію та громадсько-політичну активність ${ }^{8}$, ще якось можна порозумітися. Врешті-решт, зазначені напрями самореалізації значно ближче до філософії, ніж до хімії. Але як пов'язати висловлену у листі до Фліса думку про філософію як споконвічну мету, скажімо, із таким пасажем 3 «Автобіографії:

Я прочитав Шопенгауера вже дуже пізно. Що стосується Нiцше, іншого філософа, передчуття та передбачення котрого часом найдивовижнішим чином збігалися (курсив мій. - В.М.) із результатами, що важко давалися психоаналізу, то саме через це я тривалий час його уникав (B.M.): для мене важливим був не пріоритет, а неупередженість [4, с. 136].

$€$ всі підстави стверджувати, що у цьому випадку ми маємо справу принаймні із надзвичайно заплутаним клубком суперечностей. Більш того, є певні підстави припустити, що у випадку із Ніцше та Шопенгауером проблема пріоритету все ж таки дуже сильно турбувала Фрейда ${ }^{9}$. Насправді деякі ідеї цих філософів критично близькі до того, що Фрейд вважав своїм оригінальним винаходом, тобто до психоаналізу. Обидва - і Шопенгауер, і Ніцше - підкреслювали величезну роль несвідомих чинників та схильність свідомості до самоомани. Шопенгауер вважав найважливішим з інстинктів сексуальність (у Фрейда - Ерос), а Ніцше наполягав на ролі агресивних та само-руйнівних імпульсів (Фрейдів Танатос). Ніцше випередив Фрейда з активним використанням поняття «сублімація», а також із думкою, що цивілізація побудо-

\footnotetext{
8 «Дружба з одним старшим товаришем по гімназії, котрий згодом став відомим політиком, певний час викликала у мене бажання теж зайнятися юриспруденцією та соціальною діяльністю. Однак з особливою силою мене приваблювало актуальне за тих часів вчення Дарвіна...; розповідь про прекрасну статтю Гете «Природа», яку я почув ... незабаром до випускних іспитів, можна сказати, визначила моє рішення записатися на курс медицини» $[4$, с.92].

9 Додатковий аргумент на користь надмірного інтересу Фрейда до власної інтелектуальної першості: 1976 р. відомий соціолог науки Роберт Мертон провів ретельний аналіз текстів Фрейда та винайшов, що як мінімум у 150 випадках їхній автор висловлювався на захист своєї наукової першості, звинувачуючи тих чи інших людей у плагіаті або стверджуючи, що будь-який зв'язок його ідей з ідеями попередників або сучасників може бути лише випадковим. Іноді Фрейд навіть бачив сновидіння, основною темою яких була його наукова першість з тих чи інших питань [14, с. 467].
} 
вана на репресії інстинктів індивіда. Так само є й певні підстави вважати, що, говорячи про незнайомство (або ознайомлення у дуже пізньому віці) з ідеями цих філософів, Фрейд принаймні трошки покривив душею. Як могла «уникнути» Ніцше та познайомитися з Шопенгауером дуже пізно молода освічена людина, що жила у Відні наприкінці 19 ст. та ще й плекала мрію про філософське осяяння? Анрі Еленбергер висловився з цього приводу досить категорично: «Наприкінці 19 ст. ідеї Шопенгауера та Ніцше обговорювалися в інтелектуальних колах настільки широко, що Фрейд просто ніяк не міг уникнути хоча б загального ознайомлення з їхніми доктринами» [7, с. 277]. Еленбергеру вторить інший всесвітньо визнаний фахівець з історії психоаналізу Френк Саловей: «Просто неможливо собі уявити, щоб Фрейд, який впродовж п'яти років був членом Читацького товариства німецьких студентів Відня, був абсолютно, як йому подобалося говорити, незалежний від Шопенгауера та Ніцше» [14, с. 468].

Можливо, Фрейд дійсно іноді дозволяв собі певну нещирість, можливо навіть, що він дійсно пішов на свідоме (або напівсвідоме, або несвідоме-це вже не так й принципово) приховування своєї безпосередньої залежності від класиків ірраціоналізму. Однак, на відміну від випадку із Ніцше та Шопенгауером, описані вище коливання-маневрування Фрейда між «філософією та хімією» пояснити банальним людським честолюбством не вдається. Як хімія, так і філософія (тим більш - натуралізм та антинатуралізм) були відкриті задовго до Фрейда, в чому він, наскільки нам відомо, ніколи сумнівів не висловлював. Більш придатні ключі до розуміння причин натуралістично-антинатуралістичної двоїстості Фрейда можна знайти в роботі вже згаданого Френка Саловея «Фрейд, біолог розуму: по той бік психоаналітичної легенди» [14]. Як випливає з назви праці, цього разу в реконструкції великих Фрейдових маневрів головна увага приділяється такій дисципліни, як біологія. Дисципліною ж, за допомогою якої Саловею вдається досягти дуже цікавих результатів, виступає соціологія знання.

Саловей зосереджує увагу на такий специфічній рисі біографії Фрейда, як наполегливе (а іноді навіть - відчайдушне) проведення ним політики власної наукової незалежності. На думку цього дослідника, однією із фундаментальних рис психоаналізу є приховане прагнення самолегітимації шляхом використання найпопулярнішої біологічної доктрини кінця XIX ст.- дарвінізму. 3 одного боку, у багатьох ідеях Фрейда можна знайти аналогії з еволюційною біологією (теорія стадій інфантильної сексуальності, вчення про культуру як репресію біологічних інстинктів, прийняття біогенетичної гіпотези Геккеля тощо). 
Це знов повертає нас до вже винайдених фактів Фрейдового натуралізму. Однак, у висловлюваннях засновника психоаналізу стосовно його зв'язку із біологією, поряд з численними біологічними алюзіями, так само, як й у випадку з хімією та філософією, можна знайти приклади спроби цей зв'язок приховати. Саловей знаходить, зокрема, такий приклад антибіологізму Фрейда: «В процесі нашої психоаналітичної роботи, - казав творець психоаналізу, - ми вважаємо за необхідне утримуватися від будь-яких біологічних припущень та уникати їх використання з пізнавальними цілями» (Див.: [14, с. 420]).

Головною причиною флуктуацій Фрейда «від та до» біології Саловей вважає бажання створити нову дисципліну (чисту психологію) i підтвердити тим самим своє самостійне, незалежне місце у науковому світі. За таких умов приховування зв'язків із біологією (Саловей називає цю настанову «крипто-біологією») цілком мало рацію, принаймні - з соціологічного погляду. Те, що в психології (проголошеній Фрейдом новою) було багато елементів біології (вже досить старої), нехай вишукують й доводять історики, творцеві ж цієї психології куди більш подобалося наголошувати на тому, що вона $є$ абсолютно незалежною (тобто чистою).

За думкою відомого сучасного біолога Едварда Вілсона [15], кожна нова наукова дисципліна має свою «антидисципліну» (більш стару науку, що колись займала провідні позиції в дослідженні відповідних феноменів). На межі XIX-XX століть такого гатунку конфлікт мав місце саме між психологією (нова дисципліна, яка тільки народжувалася) та біологією (більш зріла дисципліна). Дійсно, на той момент була велика загроза, що більш розвинута антидисципліна (біологія) редукує нову дисципліну (психологію) до своїх власних принципів. В деяких напрямках психології XX ст. саме це й відбулося: біологія (або фізіологія) просто поглинула психологію (візьмемо, наприклад деякі радикально біологізаторські версії психології у радянській психології першої половини XX ст.). В цьому плані Фрейд, бажаючи створити власний психологічний напрям, був просто змушений зайнятися крипто-біологізацією психології, а його послідовники - знищенням навіть натяків на біологічні коріння в історії психоаналізу ${ }^{10} .3$ іншого боку, абсолютно відірватися від біології теж було досить складно - внаслідок недостатньої розвиненості психології та внаслідок значно більшої

\footnotetext{
${ }^{10}$ Боротьба за дебіологізацію образу психоаналіза дійшла до того, що в капітальній біографії Фрейда, що була написана одним з його найвідданіших послідовників Ернестом Джонсом, з'явилася глава, у якій замість внеску біології у розвиток ідей Фрейда обговорювався внесок Фрейда у розвиток біології.
} 
популярності науково-природничого ідеалу знання ${ }^{11}$. Фрейд прекрасно розумів, що успіх його винаходу (психоаналізу) значною мірою залежатиме від того, наскільки обгрунтованим з емпіричного погляду він виглядатиме. Тому він допускав у свої конструкції велику кількість науково-природничих елементів (тобто був натуралістом), чим, як йому принаймні здавалося, сприяв успіхові своєї теорії.

Саме цим мотивом - бажанням досягти якомога більшої автономії та, одночасно, якомога шириої рецепцї-можна, на нашу думку, пояснити й усі розглянуті вище коливання Фрейда (між філософією та хімією, юриспруденцію та медициною і загалом - між натуралізмом та антинатуралізмом). Він не хотів бути ізгоєм і тому постійно натякав на свій зв'язок з домінантною традицією, але він також не хотів, щоб його творіння просто розчинилося у вже наявних дисциплінах, i тому постійно утруднював проведення однозначних паралелей між психоаналізом та іншими галузями природознавства (біологією, хімією, фізіологією, анатомією, медициною), а іноді й робив заяви у дусі філософського антинатуралізму. Навіть у пасажі про хімію як фундамент психології, наведеному Блюменбергом, Фрейд далекоглядно виключив можливість одразу відкинути психологію на користь хімії, сказавши, що «цього фундаменту ми ще не знаємо» (див. вище). Блюменберг дуже чітко помітив амбівалентність Фрейда стосовно користі, яку міг би мати розвиток хімії для психології ${ }^{12}$, та дав цій двоїстості абсолютно чітке соціологічно-наукове пояснення. Відкриття хімічного фундаменту психології призвело би до зникнення останньої як професії:

\footnotetext{
$113 а$ часів Фрейда ще було далеко до розуміння того факту, що сцієнтизм науково-природничого гатунку намагається колонізувати гуманітарні та соціальні науки не стільки за допомогою методів об'єктивного, емпіричного пізнання, скільки за допомогою того, що представники гуманітарних та соціальних дисциплін помилково вважають за об'єктивні методи природничих наук (Див., наприклад: [13]).

${ }^{12}$ Блюменберг каже: «Утім, цю тезу про попередній характер психоаналізу, яку Фройд експліцитно висловив і на який він навіть наголошував, він розвивав украй скромно» [1, с. 454]. Більшість сучасних українських фахівців (зокрема - перекладач щойно наведеного фрагменту Володимир Єрмоленко) схиляються до думки, що український варіант прізвища засновника психоаналізу має бути похідним від його німецькомовного прочитання - Фройд. На думку автора даної статті, подібний підхід не зовсім відповідає реальному стану справ. Чому, перекладаючи прізвище єврея, який сам народився на території теперішньої Чехії (зараз-м. Пшибор), а обидва батьки якого народилися на території України (батько -у м. Тисмениця, Івано-Франківська обл., мати-у м. Броди, Львівська обл.; докладніше про українські корені Фрейда див.: [3]), ми маємо слідувати німецькому (навіть - не австрійському) зразку? Тим більш, що в ідишмовному середовищі, з якого власне всі вони й вийшли, це прізвище читалося саме як Фрейд, а не Фройд.
} 
Говорити пацієнтові, як глибоко його страждання вкорінене в його власній життєвій історії. .. і тільки через неї стає зрозумілим, - втратило би будь-який сенс, якби можна було б каузально викорінити його симптоми [1, с. 455].

Можна навести ще цілу низку прикладів задля підсилення нашої гіпотези про те, що у стосунках Фрейда 3 натуралізмом та антинатуралізмом основною стратегічною метою було досягнення наукової незалежності, а головним тактичним засобом - маневрування (або коливання) між цими двома конкуруючими настановами. Наприклад, хоча Фрейл стало наголошував на тому, що всі свої відкриття психоаналіз робить індуктивно, утім він дав багато підстав вважати, що його теорії сформовані абсолютно протилежним - гіпотетико-дедуктивним - шляхом ${ }^{13}$. Саме за відсутність емпіричного базису та зловживання спекулятивними припущеннями зазнала суворої критики Фрейдова теорія церебрального паралічу (див. вище). Свої теорії сновидінь або, скажімо, інфантильної сексуальності Фрейд позиціонував як суто науково-емпіричні, однак позитивна рецепція відповідних праць від самого початку пішла зовсім не по лінії професійної медицини, а разом із творами таких неакадемічних мислителів, як, наприклад, ті самі Ніцше з Шопенгауером, або О. Вейнінгер та В. Розанов. Фрейд любив підкреслювати, що йому подібна рецепція не дуже до вподоби, але увагою з боку найбільш просунутих любителів «пофілософувати поза стінами Академї» скористався повною мірою (М. Бонапарт, С. Далі та армада інших шанувальників вільної думки $)^{14}$. Фрейдова техніка лікування істерії за допомогою так званого «катарсичного методу» була сприйнята деякими його сучасниками не як науковий прогрес, а як повернення до старовинного методу лікування душевних розладів шляхом вигнання демонів. Анрі Еленбергер, зі свого боку, висловив припущення, що мотивом, котрий спонукав Фрейда до прийняття на озброєння «катарсичного методу», були не стільки емпіричні факти лі-

\footnotetext{
${ }^{13}$ Наприклад, Фрейд підкреслював, що його теорії неврозів, сновидінь, помилок та дотепності, незважаючи на те, що вони дуже схожі між собою за внутрішньою структурою, є результатами окремих емпіричних досліджень, що проводилися в різні часи та $з$ позицій абсолютно незацікавленого наукового спостереження. Однак, на думку Еленбергера, їхня дивна структурна схожість свідчить скоріше про те, що ті три з них, що з'явилися хронологічно пізніше, були насправді дедуковані з хронологічно першої (теорії неврозів), а зібрані згодом емпіричні підтвердження були пристосовані до вже наявної парадигмальної гіпотези (Докладніше про це: [7, c. 489-500].

14 Докладніше про рецепцію Фрейда як «популярного філософа» можна дізнатися, скажімо, від Еленбергера. Див., напр.: [7, с. 502-510].
} 
кування Анни О., скільки широка популярність поняття «катарсису» у віденських освічених колах відповідних часів ${ }^{15}$.

Згадка про здійснюване Фрейдом спільно з Йозефом Брейєром лікування Анни О., в процесі якого народилася ідея «катарсичного» методу лікування істерії, виводить наш розгляд на ще один випадок з лікарської практики майбутнього засновника психоаналізу. Обидві історії хвороби хронологічно дуже близькі - лікування відбувалося наприкінці XIX ст., тобто ще напередодні появи «Тлумачення сновидінь» i, відповідно, публічного народження психоаналізу як специфічного ідейного напрямку. Однак, на відміну від історії з Анною О., яку здавна та дуже активно використовують прихильники психоаналізу як один із прикладів раннього професійного тріумфу їхнього кумира, історія хвороби, до якої ми хочемо звернутися зараз, майже забута. Вже сама по собі прихованість цієї сторінки історії психоаналізу - гарний привід спробувати придивитися до неї уважніше. Однак, на нашу думку, аналіз цього епізоду професійної біографії Фрейда може бути надзвичайно корисним і задля реалізації основної мети даної статтідосягнення більш глибокого розуміння ставлення Фрейда до таких пізнавальних настанов, як натуралізм та антинатуралізм. Ексклюзивне значення цього епізоду полягає в тому, що це, наскільки нам відомо, єдиний випадок, коли Фрейд перейшов з однієї позиції на протилежну раз $і$ назавжди.

Зараз майже всі, хто згадує ім'я Зигмунда Фрейда, насамперед пригадують його теорію, згідно з якою несвідоме кожної людини містить сексуальний потяг до одного з батьків або близького родича протилежної статі («комплекс Едипа» у чоловіків та «Електри»-у жінок) і саме цей мотив лежить в основі багатьох душевних хвороб, сновидінь, міфів, та майже всієї людської культури загалом. Надзвичайно важко уявити такого Фрейда, який не тільки давав собі раду без цієї концепції, а ще й був прихильником абсолютно протилежного погляду. Але це історичний факт: вже отримавши ступінь доктора та розпочавши власну медичну кар'єру, Фрейд сповідував теорію зваблення, згідно 3 якою інцест - зовсім не фантастичний продукт прихованого у несвідомому психологічного комплексу, а сумна фізична реальність, яка заскочує деяких дітей через аморальність деяких дорослих. Певний час молодий доктор Фрейд вважав, що саме внаслідок пережитого у дитинстві реального зваблення у деяких людей може розвинутися та-

\footnotetext{
$15 \mathrm{y} 1880$ р., наприклад, книжку про поняття «катарсис»у Арістотеля видав дядько майбутньої дружини Зигмунда Фрейда - Якоб Бернайс (Див.: [7, с. 484].
} 
ке захворювання, як істерія. Лише згодом він змінив свою точку зору і став рішуче відстоювати ідею, що коріння істерії слід шукати не у реальних (натуральних) фактах зваблення дітей дорослими, а у вигаданих (антинатуральних) інцестуальних сценах та у їхніх несвідомих (апріорних, трансцендентальних?) передумовах у вигляді інцестуальних комплексів. Коли, як і чому він зробив цей «великий маневр»?

Перші спроби знайти відповіді на ці запитання, так само як і власно виведення факту «маневру» із глибокого несвідомого історії психоаналізу, були зроблені американським дослідником Джефрі М. Масоном у його досить контроверсійній, але надзвичайно важливій для розуміння корінь психоаналізу праці під назвою «Замах на правду: Фрейдове приховування теорії зваблення» [12]. Працюючи над підготовкою до видання повного зібрання листів Фрейда до Вільгельма Фліса, Ма$\mathrm{coн}^{16}$ звернув увагу на той факт, що за усіма купюрами, зробленими для першого видання цих листів особисто дочкою Фрейда Анною, простежується певна логіка:

3 листів, що були написані після вересня 1897 р. (тобто того самого моменту, коли Фрейд вирішив відмовитися від своєї теорії зваблення), були вилучені всі історії хвороби, які хоч якимось чином могли цю теорію підтверджувати. Білњш того, було вилучено також абсолютно всі пригадування про Ему Екштейн -

\footnotetext{
${ }^{16}$ На нашу думку, дуже важливими є фактичні обставини початку, дострокового припинення та результатів дослідницької роботи Масона у Фрейдових архівах. 1970 р. Джефрі Мусаєф Масон закінчив Гарвардський університет (докторський ступінь за фахом «санскрит»), після чого вступив до Інституту психоаналізу в Торонто. Майже одразу Масон зацікавився обставинами виникнення психоаналітичного вчення. Відчувши дефіцит інформації з даного питання, він замислився над можливістю видання найважливішого історичного документу - листування Фрейда з Вільгельмом Флісом, що був найближчим приятелем Фрейда саме напередодні створення психоаналізу. Окремі епістолярні свідчення цієї епохальної дружби на той час вже були опубліковані (за редакцією дочки Фрейда Анни). На думку Масона, важливість теми диктувала необхідність видати це джерело інформації не частково, а цілком. 3 цією пропозицією Масон наприкінці 1970-х років звернувся до Анни Фрейд та Курта Ейслера, який на той час був директором архіву Зигмунда Фрейда. На початку 1980 р. Масон отримав не тільки дозвіл на підготовку повного видання листування Фрейда з Флісом, але й позицію директора Фрейдового архіву. Кількома місяцями пізніше (у серпні 1980 р.) він надрукував у газеті The New York Times серію статей з першими результатами своїх архівних студій, після чого був негайно звільнений із щойно зайнятої посади та виключений з психоаналітичної асоціації. У психоаналітичних колах ці публікації Масона були кваліфіковані як «інтелектуальний тероризм». Вже у статусі ворога психоаналізу Масон розвинув свої припущення у книзі «Замах на правду: Фрейдове приховування теорії зваблення», аналізу якою ми й присвятимо майже всю решту даної статті.
} 
ранню пацієнтку Фрейда та Фліса, хвороба якої мала певне відношення до тієї самої теорії зваблення [12, с. XXV].

Це несподіване спостереження спонукало Масона пильніше придивитися до обставин, за яких Фрейд вирішив відмовитися від своїх вихідних поглядів. 1885 р., незабаром після закінчення Віденського університету, Фрейд поїхав на стажування до Парижу. Саме під час свого перебування у Франції він отримав численні фактичні підтвердження реальності актів фізичного та сексуального насильства стосовно дітей та підлітків з боку їхніх старших родичів. Слід зазначити, що на момент прибуття Фрейда на береги Сени французькі дослідники, що жили і діяли в атмосфері значно більшого лібералізму і вільнодумства, ніж їхні австрійські колеги тієї пори, встигли оприлюднити величезну кількість емпіричних свідчень реальності таких трагедій ${ }^{17}$. Ще одна відмінність французької медичної школи від австрійської торкнулася Фрейда найбезпосереднішим чином. Усі паризькі студенти-медики були зобов'язані три рази на тиждень відвідувати морг. Демонстрації в морзі, що проводилися під час перебування Фрейда у Парижі ${ }^{18}$, були покликані наочно продемонструвати численні факти згвалтування дітей дорослими. 3 таким багажем нових знань Зигмунд Фрейд

\footnotetext{
${ }^{17}$ Наприклад, ще 1860 р. у впливовому медичному журналі Annales d'hygiène publique et de médecine légale була опублікована стаття професора Паризького університету А.-О. Тардьє «Медико-юридичне дослідження жорстокості і брутального ставлення до дітей», у якій було зібрано і каталогізовано велику кількість прикладів насильства (зокрема - сексуального) щодо дітей. Праці Тардьє послужили могутнім стимулом до народження особливої традиції досліджень у французькій психіатричній школі. 1882 р., тобто за три роки до приїзду Фрейда до Франції, ЖК.М. Шарко у співавторстві з іншим відомим психіатром Валентином Маньяном опублікував статтю «Інверсія генітального відчуття та інші сексуальні перверсії», де, явно не без впливу Тардьє, був зроблений акцент на наявності у деяких дорослих людей сексуального потягу до дітей.

18 Демонстрації проводилися спадкоємцем Тардьє (див. попереднє посилання) на посаді завідувача кафедрою медичної криміналістики Полем Броделем. На момент перебування Фрейда в Парижі лекції з цієї тематики, що читалися Броделем студентам та наочно ілюструвалися їм же в стінах Паризького моргу, усе ще не були опубліковані. Дослідження Броделя були видані лише після його смерті-1909 р. Однак, за думкою Масона, Фрейд, як слухач Броделя, не міг не знати про те, що такі розробки ведуться. Знав він також і про висновки, яких дійшов Бродель. У книзі останнього детально описуються 232 випадки згвалтування малолітніх, що супроводжувалися жорстокими побиттями та іншими проявами садизму. У дев'ятнадцяти з них винуватцями були рідні батьки, у шести - дядьки, а у чотирьох вітчими жертв. Тобто кожен десятий випадок такого роду був інспірований кимсь із членів родини. Переважна більшість випадків, зібраних в роботі Броделя, датується 1880-1885 рр., що, на думку Масона, служить додатковим підтвердженням припущення, що Фрейд не міг не бути у курсі.
} 
повернувся до Відня, де панували зовсім інші настрої-як стосовно емпіричної основи навчання медицині в університеті ${ }^{19}$, так і стосовно можливості фактів, демонстрацією яких студентам займалися університетські професори у Франції.

Через декілька років після повернення із Франції Фрейд розпочав приватне лікування Еми Екштейн - 29-річної пацієнтки, що мала утруднення з ходьбою, страждала від нерегулярних і вкрай хворобливих менструацій, а також повідомила Фрейду про те, що у дитинстві пережила сексуальну агресію з боку власного батька. Фрейд розповів про цю пацієнтку Вільгельму Флісу, який дотримувався досить екстравагантної думки, що захворювання статевих органів пов'язані $з$ носовими проблемами, і тому запропонував як лікувальний засіб назальну хірургію. У лютому 1895 р. Ема Екштейн була прооперована Флісом, але, на жаль, вкрай невдало: стан жінки тільки погіршився, вона взагалі опинилася на межі смерті. Фліс попросту забув просякнутий йодом півметровий шматок марлі в порожнині, що утворилася після видалення у Еми носової раковини. Це викликало обширне запалювання та від фатального фіналу жертву експерименту врятувало лише негайне втручання інших хірургів.

Такий результат операції, здавалося б, мусив пробудити у Фрейда серйозні сумніви у спроможності Фліса як лікаря, однак сакралізація образу єдиного й найкращого друга, виявилася сильнішою ${ }^{20}$. Рятівною соломиною виявилася ідея про те, що насправді усі симптоми пацієнтки, включаючи і майже передсмертний стан після операції, є результатом жахливої травми, що була отримана в дитинстві. Глибока розхитаність психіки пацієнтки була визнана похідною від сексуального насильства з боку батька. Від хворобливих спогадів про реальну травматичну подію жодна операція вилікувати не могла в принципі. Питання про недбале проведення операції у цьому контексті також ставало

\footnotetext{
${ }^{19}$ Програмою навчання у Віденському університеті такі інтенсивні практичні заняття із студентами-медиками, як у Парижі, не передбачалися. Наприклад, коли Фрейд обіймав посаду доцента, він взагалі не мав доступу до клінічного матеріалу (Див.: [1, с. 459]).

${ }^{20}$ Макс Шур ще у 1950-ті роки на підставі ознайомлення із листами Фрейда до Фліса дійшов висновку, що Фрейд доклав «відчайдушних зусиль заради того, щоб не допустити навіть гадки про те, що за цю помилку будь-який суд мусив би звинуватити Фліса у професійній неспроможності» (Schur M. The Guilt of the Survivor. Стаття не була опублікована. Ї̈̈ рукопис зберігається в архівах Бібліотеки Конгресу США (Цит. по: [12, с.68])). За думкою А. Еленбергера, між Фрейдом та Флісом мали місце надзвичайно специфічні стосунки, що нагадували радше не стосунки двох вчених, а містичне посвячення у шамани шамана-учня (Фрейда) шаманом-вчителем (Флісом). Докладніше про це: [2].
} 
лише технічним нюансом. Міркуючи над подальшою конструктивною стратегією лікування Еми (рятувати, а не шукати винних!), Фрейд сконцентрував увагу на сексуальній травмі як причині всіх інших проблем пацієнтки. Так захист провиненого напарника підштовхнув його до формулювання спеціальної теорії етіологічних корінь істерії- теорії зваблення.

Свідчення формування цієї теорії можна знайти в роботах Фрейда, написаних незабаром після невдалої операції над Емою Екштейн. Так, наприклад, у статті «Спадковість та етіологія неврозів» Фрейд стверджував:

Подія, про яку суб'єкт зберігає несвідомі спогади, являє собою передчасний досвід сексуального зв'язку, що супроводжувався актуальним збудженням геніталій та був результатом сексуального насильства, заподіяного іншою особою; відбувається ця фатальна подія у найранішій юності - у віці до 8-10 років, тобто ще до того, як дитина досягла статевої зрілості [9, с. 152].

У цій же статті, що була опублікована у березні 1896 р. у Франuіï, Фрейд із вдячністю згадав про одного із тамтешніх прихильників цього погляду (Шарко) і рішуче відмежувався від тих французьких психіатрів (таких, наприклад, як Альфред Фурньє), які, підігруючи обивательським догмам, говорили про «симуляцію» Згвалтування та про споконвічну «дитячу неправдивість». Контраргумент Фрейда варіанта 1896 р. був надзвичайно простий: вигадати таке дитина просто не в змозі. Як вважає Масон, у цій статті є також і важлива новація Фрейда у порівнянні з працями Шарко, Броделя, Тардьє та інших прихильників реальності фактів сексуальної агресії до дітей: «В усіх цих книгах не було ані слова про психологічні наслідки для дитини». Цю, на думку Масона, історичну місію виконав Зигмунд Фрейд, який поспішив повідомити про це не тільки своїх французьких колег, але й світил віденської медицини.

21 квітня 1896 р. Фрейд виступив на засіданні Віденського товариства психіатрів і неврологів з доповіддю про етіологію істерії. Доповідач заявив, що істерія розвивається у людей, що у дитинстві стали жертвами сексуального зваблення з боку дорослих (нерідко - когось з родичів). Однак реакція професійного співтовариства була однозначно негативною. На відміну від ліберально налаштованих французів, віденські лікарі були свято переконані у глибокий моральності абсолютної більшості своїх високоповажних співгромадян, включаючи батьків й інших близьких родичів своїх пацієнтів. Ось що написав Фрейд 
про це засідання у своєму листі до Фліса декількома днями пізніше:

У цих віслюків із психіатричного товариства моя лекція 3 етіології істерії зустріла крижаний прийом, а Крафт-Ебінг ${ }^{21}$ зробив дивний коментар: «Звучить як наукова казка». I це після того, як їм було продемонстровано розв'язання проблеми, що настільки гостро стоїть вже більш тисячі років, після того, як їм був вказаний «виток Нілу»! Так пішли вони усі до пекла! [10, c. 184]

Процитований текст у першому (неповному) виданні листування Фрейда з Флісом [11] був відсутній. Здавалося б, це не зовсім логічно: Анні Фрейд, що пеклася про титанічний образ свого батька, цей гнівний пасаж мав би бути до вподоби. На думку Масона, причина вилучення цього листа із видання, яке редагувала дочка Фрейда, полягала у тому, що невдовзі після його написання її батько сам відмовився від теорії зваблення ${ }^{22}$. Замість неї він винайшов нове пояснення істерії, що стало в повному розумінні слова наріжним каменем психоаналітичної теорії у тому виді, у якому ми їі знаємо нині. Фрейд заявив, що клінічний досвід продемонстрував невірність його попередніх тверджень про те, що основною причиною неврозів є справжні сексуальні травми. Цей же клінічний досвід нібито згодом і змусив його визнати, що, всупереч розповідям пацієнтів, жодних реальних сцен сексуального зваблення у них в дитинстві не було і що насправді ці «пригадування» травматичного досвіду являють собою лише фантазії хворих на істерію. Відповідно, абсолютно змінилася стратегія лікування: якщо у доповіді на засіданні психіатричного товариства Фрейд пропонував лікувати істериків від наслідків фактичного зваблення або згвалтування, то після цього «маневру» зцілення полягало у переконанні пацієнтів у тому, що подібні сцени є продуктом їхньої фантазї, навіть якщо вони абсолютно переконані у зворотному.

\footnotetext{
${ }^{21}$ Барон Рихард фон Крафт-Ебінг - відомий австрійський психіатр; на момент описуваних подій - керівник кафедри психіатрії Віденського університету та головуючий на тому засіданні.

${ }^{22}$ Про те, наскільки сильним було бажання Фрейда забути про теорію зваблення, може свідчити такий факт. За рік до своєї смерті, залишаючи аншлюсовану нацистами Австрію, Фрейд не побажав взяти у свою, як він прекрасно розумів, останню подорож деякі томи з особистої бібліотеки. У переліку залишених у Відні книжок присутні всі ті роботи французьких авторів другої половини XIX ст., у яких доводилася реальність фактів сексуального зваблення дітей їх рідними. «Виглядає це так,- говорить Масон,- немовби він намагався стерти зі своєї свідомості усі спогади про їхній зміст» [12, с. 38].
} 
Що було причиною такої трансформації поглядів? Пояснення, запропоноване Масоном, має право на існування, але, на нашу думку, $\epsilon$ надто конспірологічним ${ }^{23}$. Однозначне переконання Масона у тому, що перша теорія Фрейда (інцест як факт) є абсолютною істиною, тоді як ㄲï альтернатива (інцест як фантазія) $€$ «замахом на правду», саме заслуговує на серйозний критичний аналіз ${ }^{24}$. Можливо, справжньою причиною «великого маневру» було бажання не втратити спільну мову iз колегами-співвітчизниками. Можливо, спрацювала логіка боротьби за наукову незалежність: якщо теорія зваблення вписувалася у традиційну емпіричну настанову біології, фізіології та навіть кримінологї, то теорія психологічних комплексів, що приховані у несвідомому, принаймні зовнішньо виглядала більш оригінально.

Наскільки цей поворот від реальних фактів зваблення до умов можливості фантазій ${ }^{25}$ про зваблення (тобто комплексів Едипа та Електри) можна вважати поворотом від натуралізму до антинатуралізму, від фактичного до трансцендентального? Зрозуміло, що повного повороту тут немає. Фрейдові комплекси не є чистими умовами можливості із суто трансценденталістської позиції. Вони несуть на собі родимі плями натуралізму та емпіризму, вони фактично навантажені. Однак, суто емпіричними вони не є також, бо надто умоглядні та жодним незаангажованим емпіричним дослідженням підтверджені не були. Можливо, в цьому і ховається таємниця успіху Фрейдового проекту - в його принциповій двосмисленості, в його емпіричній умоглядності або

\footnotetext{
${ }^{23}$ На думку Масона, теорія зваблення була відкинута Фрейдом виключно внаслідок категоричної незгоди з нею Фліса (того самого Фліса, з метою захистити якого Фрейд її власно і сформулював). Лише через багато десятиліть син Фліса Роберт, дитинство якого прийшлося на ті роки, коли відбувалися описувані події, зізнався, що йому довелось стати жертвою сексуальної активності з боку власного батька. За словами Масона, Фрейд опинився в ролі детектива-невдахи, що на порозі розкриття страшного злочину почав ділитися своїми підозрами, передчуттями, а під кінець і відкриттями з людиною, яка сама цілком годилася на роль підозрюваного.

${ }^{24} \Theta$ повідомлення про випадки, коли психотерапевти, що занадто сильно солідаризувалися з ідеями Масона, буквально силоміць витягували зі своїх клієнтів хибні зізнання про те, що їх у дитинстві нібито зваблювали або гвалтували їхні старші родичі (Докладніше про це: [6, с. 201]).

${ }^{25}$ Перекладач Блюменберга Володимир Єрмоленко висунув припущення, що вчення про фантастичну природу зваблення може вважатися оригінальною Фрейдовою версією трансценденталізму. Специфіка цього трансценденталізму, на його думку, полягає в тому, що, на відміну від традиційного, Фрейдів трансценденталізм заснований на понятті «умови неможливості». В. Єрмоленко звертає увагу на те, що, за Фрейдом, культура може бути розглянута як «умова неможливості» здійснення бажання. Автор даної статті сподівається, що ці цікаві припущення знайдуть розвиток у подальших наукових розробках вельмишановного колеги.
} 
натуральній ненатуральності? Можливо, ця єдність ідеального та реального споріднює фрейдизм з такими найдавнішими символічними формами, як міф, релігія та мистецтво, і через те робить його безсмертним? Можливо, вердикт, що виносився Фрейду багато разів та на різні лади (скажімо, так: «Вишуканий митець думки тріумфує над науковим дослідником» $\left.{ }^{26}\right)$, зовсім і не $\epsilon$ вердиктом? До речі, не виключено, що саме через описані вище маневри батька психоаналізу тільки й могла народитися психологія, якою ми знаємо її зараз, тобто як окрема академічна дисципліна.

\section{1 Бібліографія}

[1] Блюменберг Г. Світ як книга / Переклад з німецької, передмова, коментарі Володимира Єрмоленка. - Київ: Лібра, 2005.

[2] Менжулин В.И. Биографическая подоплека в истории психоанализа и понятие «творческой болезни» // Вісник МСУ. Юдаїка. 8/2002. - C. $130-145$.

[3] Романець Д. Українські корені Зигмунда Фрейда (інтерв'ю з В. Менжуліним.). - «Україна молода». - № 81 (від 5 травня 2006 p.). - С. 19. Електронний варіант даного тексту можна знайти за адресою: http://www.umoloda.kiev.ua/number/667/169/24232/

[4] Фрейд 3. Автобиография / Пер. с нем. М. Харитонова // Фрейд 3. По ту сторону принципа удовольствия. - М.: Прогресс, 1992.C. 91-148.

[5] Шур M. Зигмунд Фрейд: жизнь и смерть / Пер. с англ. Л.А. Игоревского. - М.: ЗАО Центрполиграф, 2005.

[6] Bauer H. Science or Pseudoscience: Magnetic Healing, Psychic Phenomena and Other Heterodoxies. - Urbana and Chicago: University of Illinois Press, 2001.

[7] Ellenberger $H$. The Discovery of the Unconscious: The History and Evolution of Dynamic Psychiatry. - New York: Basic Books, 1970.

[8] Freud S. Die Struktur der Elemente des Nervensystems // Jahrbücher für Psychiatrie. - V (1884). - S. 221-229.

\footnotetext{
${ }^{26}$ Оцінка, що була надана Фрейдові одним з перших рецензентів «Тлумачення сновидінь» (Hugo Liepmann) ще у 1901 р. (Цит. по: [14, с. 456]).
} 
[9] Freud S. Heredity and the Aetiology of the Neuroses // Freud S. The Standard Edition of The Complete Psychological Works. - London: Hogarth Press and the Institute of Psycho-Analysis, 1953-1974. - Vol. 3. - P. 143-156.

[10] Freud S. The Complete Letters of Sigmund Freud to Wilhelm Fliess, 1887-1904 / Translated and Edited by Jeffrey Moussieff Masson. Cambridge-London: The Belknap Press of Harvard University Press, 1985.

[11] Freud $S$. The origins of psycho-analysis; letters to Wilhelm Fliess, drafts and notes, 1887-1902 / Edited by Marie Bonaparte, Anna Freud [and] Ernst Kris; authorized translation by Eric Mosbacher and James Strachey. Introd. by Ernst Kris. - New York: Basic Books, 1954.

[12] Masson J. The Assault on Truth: Freud's Suppression of the Seduction Theory. - New York: Farrar, Straus and Giroux, Inc., 1984. Цитати з даної роботи ми будемо наводити за їі другим виданням: (New York: Penguin Books, 1985).

[13] Popper K. A Pluralist Approach to the Philosophy of Science // Streisler, E. et al., eds. Roads to Freedom: Essays in Honour of F.A. Hayek. London: Routledge and Kegan Paul, 1969. - P. 181-200.

[14] Sulloway F. Freud: Biologist of the Mind: Beyond the Psychoanalytic Legend. - Cambridge: Harvard University Press, 1992.

[15] Wilson E. Biology and social sciences // Daedalus. - 1977, Fall. P. 127-140. 